\title{
Treegazing: How Art and Meditation Connect Peripatetic Practices as a Form of Subtle Activism
}

\author{
Heather Hesterman \\ RMIT University, Australia \\ hs.hesterman@utas.edu.au \\ Amanda Hawkey \\ Melbourne Insight Meditation, Amayoga, Australia \\ amandahawkey@mac.com
}

\begin{abstract}
Treegazing was a public walking event held in the Fitzroy Gardens, Melbourne, Australia in 2020 inviting the public to lift their gaze and be mindful whilst acknowledging the garden's aesthetic design and history. This walk created a temporary community of strangers who co-experienced the majestic arboreal canopies of trees and plants, reducing 'plant blindness' (Schussler \& Wandersee, 1998). Acknowledging the importance of 'what stories are told' and 'making-kin' (Haraway, 20I6), this article explores collaborative visions between meditation practitioner Amanda Hawkey and artist Heather Hesterman. The act of mindful walking aims to connect the body to green spaces; to provide an embodied experience of nature. How might fundamental practices, as humans walking together in public space be potential acts of transformation, of mindfulness, and environmental awareness - even subtle activism? We argue that encouraging an engagement with nature via haptic and ocular modes of art practice and meditation may facilitate a deeper engagement with plants. Treegazing invites the walkers to become part of a connective- fluidity that enacts space not within as participants, witness nor viewers but offers a shared collective experience of both mobility and stillness with the landscape, a subtle activism that looks up and treads lightly to 'conspire - with nature.'
\end{abstract}

Keywords: public garden, walking, perception and senses, interdisciplinary, politics

To cite this article:

Hesterman, H., Hawkey, A. (2020) Treegazing. How Art and Meditation Connect Peripatetic Practices as a Form of Subtle Activism, The Journal of Public Space, 5(4), 23I-244, DOI 10.3289I/jps.v5i4.1423

This article has been reviewed by the Editors and accepted for publication in The Journal of Public Space. (C) This work is licensed under a Creative Commons Attribution - Non Commercial 4.0 International License https://creativecommons.org/licenses/by-nc/4.0/ 


\title{
Acknowledgement of Country
}

We acknowledge the Traditional Owners of the land on which we meet, the Boon Wurrung (Bunurong) and Woi Wurrung (Wurundjeri) peoples of the Eastern Kulin Nation. We recognise that sovereignty of this land was never ceded. We pay our respects to elder's past and present and acknowledge all First Nation peoples.

Staying alive- for every species- requires liveable collaborations. Collaboration means working across difference, which leads to contamination.

Without collaborations, we all die.' - Anna Tsing'.

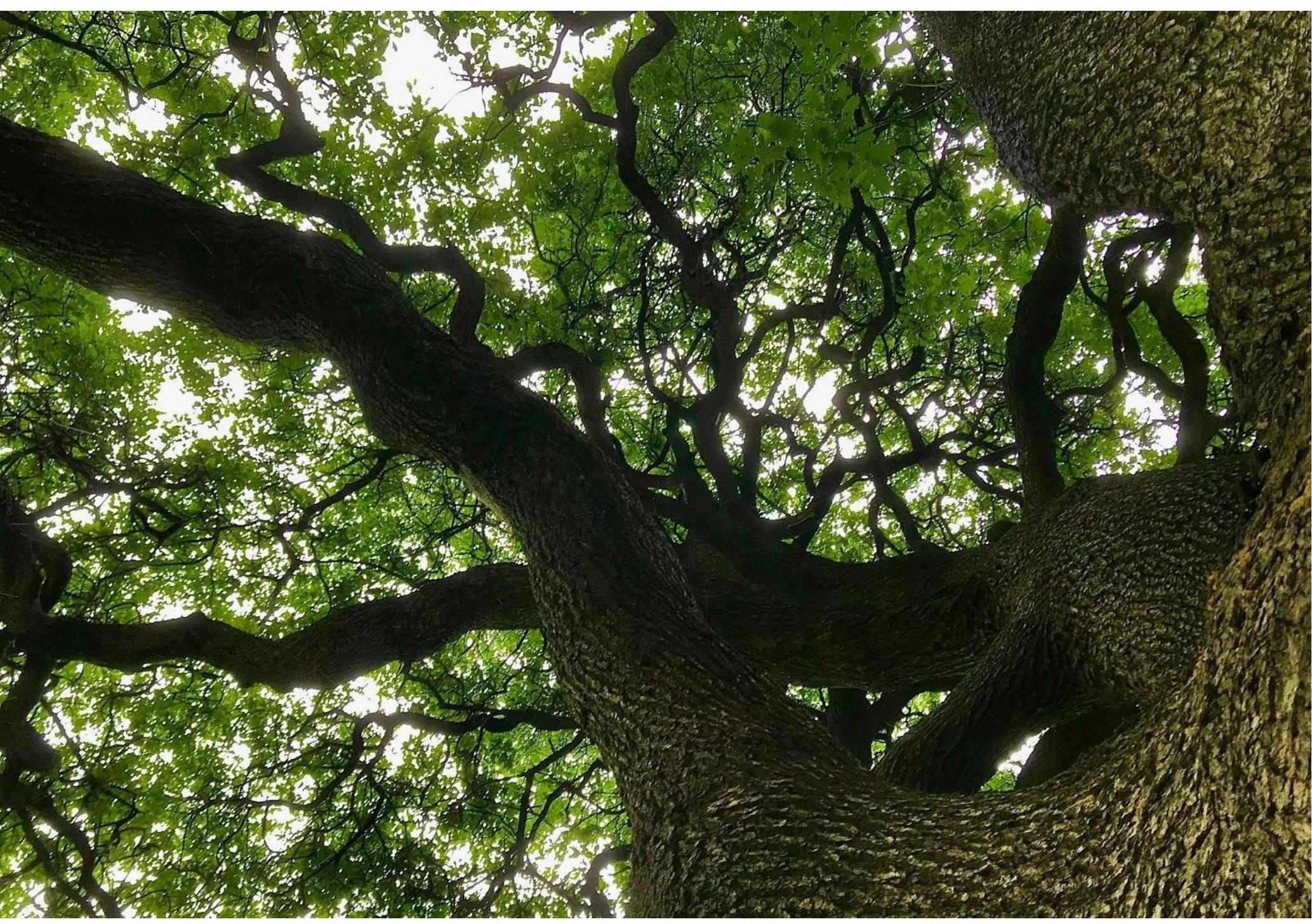

Figure I. Arboreal canopy. 2019 Image credit: Heather Hesterman

\begin{abstract}
' Anna Tsing writes that 'to learn anything we must revitalize arts of noticing and include ethnography and natural history. But we have a problem with scale. A rush of stories cannot be neatly summed up. Its scales do not nest neatly; they draw attention to interrupting geographies and tempos.'p 37. Our intention was to touch upon the histories of the garden as we knew, offering stories that attempted to reveal the layers in a non-linear narrative.
\end{abstract}

232 | The Journal of Public Space, 5(4), 2020 | ISSN 2206-9658

City Space Architecture / UN-Habitat 
Treegazing was a collaborative project for Melbourne Design Week 2020 by Amanda Hawkey and Heather Hesterman formed through our shared interests of trees and walking. We wondered if the intersections of our practices could be shaped and shared with others as a mode of exploring our connections to the living world. The interstitial space between our practices is messy and complex. However, from our collaborative composting (Haraway, 2016) new forms and awareness may arise.

Treegazing offered free walks starting from the Treasury Gardens located at the edge of the busy Melbourne Central Business District through to one of the oldest gardens in Melbourne's Central Business District, Fitzroy Gardens. The subtext was to draw attention to 'living' collaborations with species 'more-than-human'(Head, 20I4).

Treegazing was not intended as a garden tour but rather through an interweaving of our practices, an alternative method of engagement with the landscape, particularly via the acts of 'noticing'. Our walk drew upon art, meditation and landscape design practices in a new hybrid form that offered contemplative directives focusing on both internal and external landscapes.

Treegazing was a political form of subtle activism.

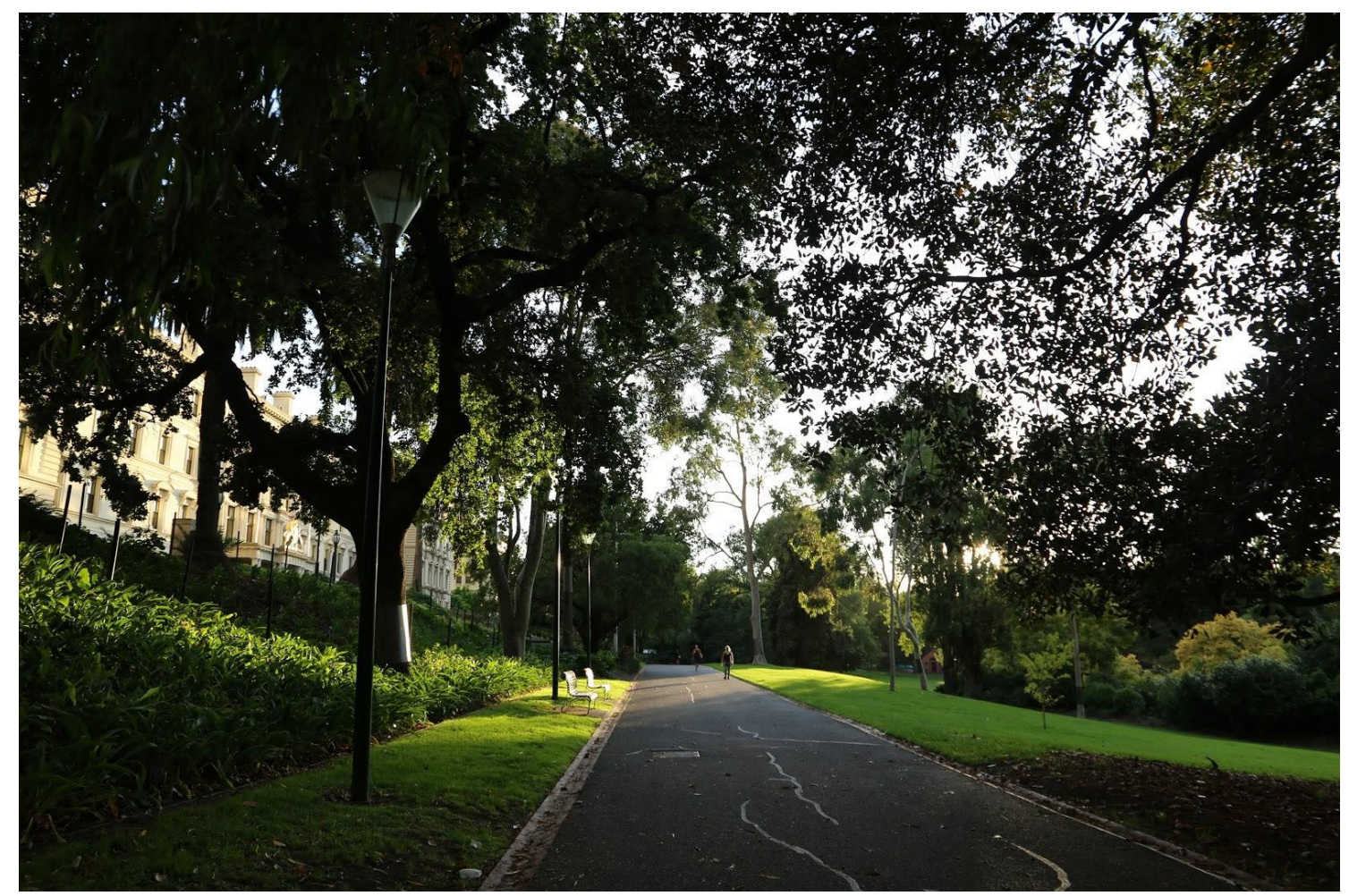

Figure 2. Walk from Treasury Gardens to Fitzroy Gardens. 2020. Image credit: Heather Hesterman

The walks were carefully curated to establish a route, pace and scripted information. We outlined a framework introducing guidelines of silence; mindful walking; 'noticing' attention and invited participants to mediative actions. This information gave walkers the 'shape of the walk' so they are aware of what to expect and to put them at ease. 
Walkers proceeded to follow more-or-less in a single file. With pre-determined methods, the walker is able to 'relax into' the walking experience, with space for sensory experiences.

We invited walkers to observe silence, for the duration of their time in the gardens. Silence is a technique employed by Contemplatives to quieten the mind and direct attention to sensory experience as stated by Pema Chodron (2020):

"If you don't fill up your time with your discursive mind, with your worrying and obsessing, you have time to experience the blessing of your surroundings. You can just be there quietly. Then maybe silence will dawn on you, and the sacredness of the space will penetrate."

This is a silence in action where the ego is not present. In the process of uniting with an activity we can forget the self and can become more intimate with the vividness of the present moment. We have a choice to step away from past conditioning and be fresh and alive in a moment-to-moment awareness (Rosenberg, 1998).

One of the meditation practices that was employed was the Buddhist practice of Mindfulness. Mindfulness can be described as, "an open-hearted awareness of our thoughts, emotions, bodily sensations and environment in the present moment" (Bunting \& Kearney, 2016). The Buddha guided that Mindfulness could be practiced in four postures, walking, standing, sitting and lying down.

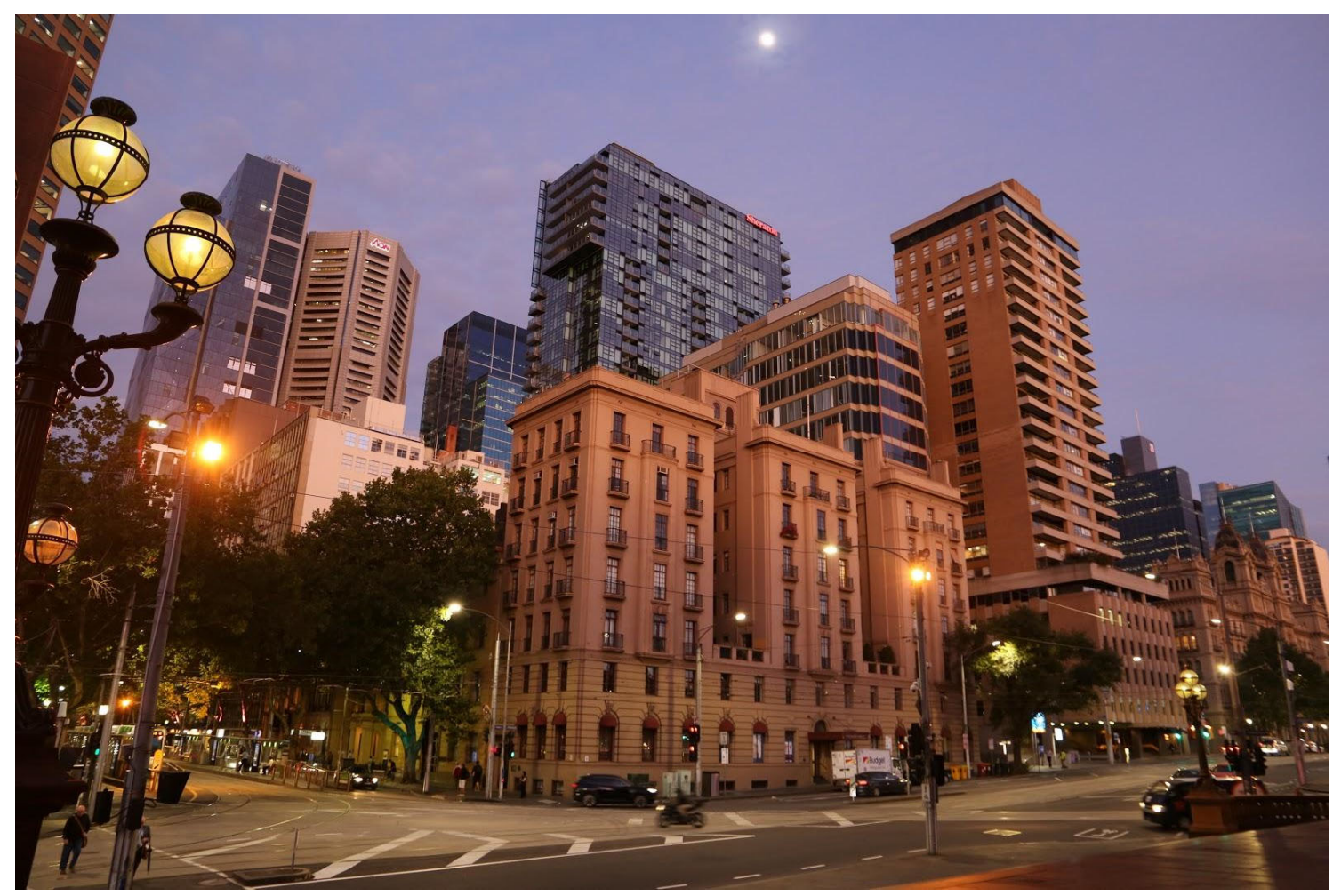

Figure 3. Melbourne. 2020. Image credit: Scarlet Sykes Hesterman 
We invited walkers to leave the busy-ness of their occupations and obligations, to leave the noise and drama of the city behind and walk with us. A slow mindful walk offers an opportunity to 'give attention to' the landscape space, and the sensory experiences of the body: hearing, seeing, smelling, tasting and touching. When attention is practised with clear understanding it can allow us to skilfully engage our attention and stay present in the now. Without attention we are lost in thinking, worrying about the past or planning for the future (Bunting \& Kearney, 2016).

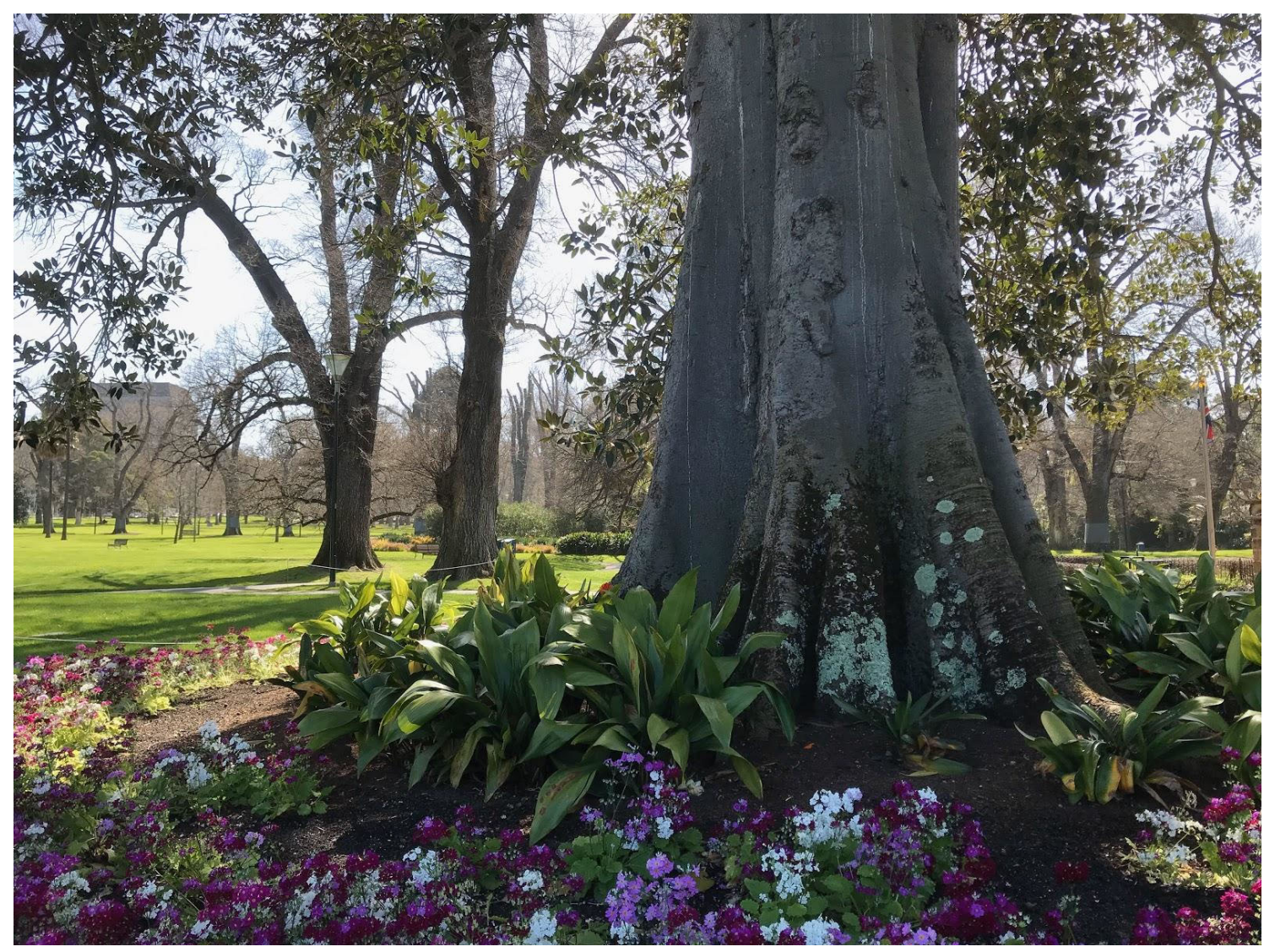

Figure 4. Colourful garden bed border at the base of a Ficus. Fitzroy Gardens. 2020. Image credit: Heather Hesterman

We asked walkers to notice. The act of 'noticing' is a form of giving attention to something (Ryle, 1949; Reich, 1995). Walkers were guided to notice surrounding colours, forms, textures, light and spaces created by the plants, design and pathways. 'Softfascination' is where the attention effortlessly rests on things that are 'fascinating' to the viewer. Stephen and Rachel Kaplan, who have researched restorative experiences suggest 'soft fascination' is an important element to enjoying the restorative aspects of nature: the view of trees; flowers and green grass can be viewed with little effort. As well, patterns in nature: clouds; motion of leaves in the breeze easily hold the attention. People find these views and patterns aesthetic and pleasurable (Kaplan, 1992).

The notion of 'plant blindness' was introduced. Botanist Elizabeth Schussler and James Wandersee coined the phrase 'plant blindness', as "the inability to see or notice plant's in one's own environment". (Schussler \& Wandersee, 1998). One of Treegazing's 
considerations was to highlight 'plant blindness', noting how the modern society has 'devalued plants' (Mancuso 2018). To develop deeper connections and understandings, plants must be viewed as complex organisms with 'sophisticated capabilities' (Mancuso, 2018). To consider vegetal-beings we need to "cultivate a thinking about plants, as well as with them and consequently, with and in the environment, from which they are not really separate" (Marder,20I3).

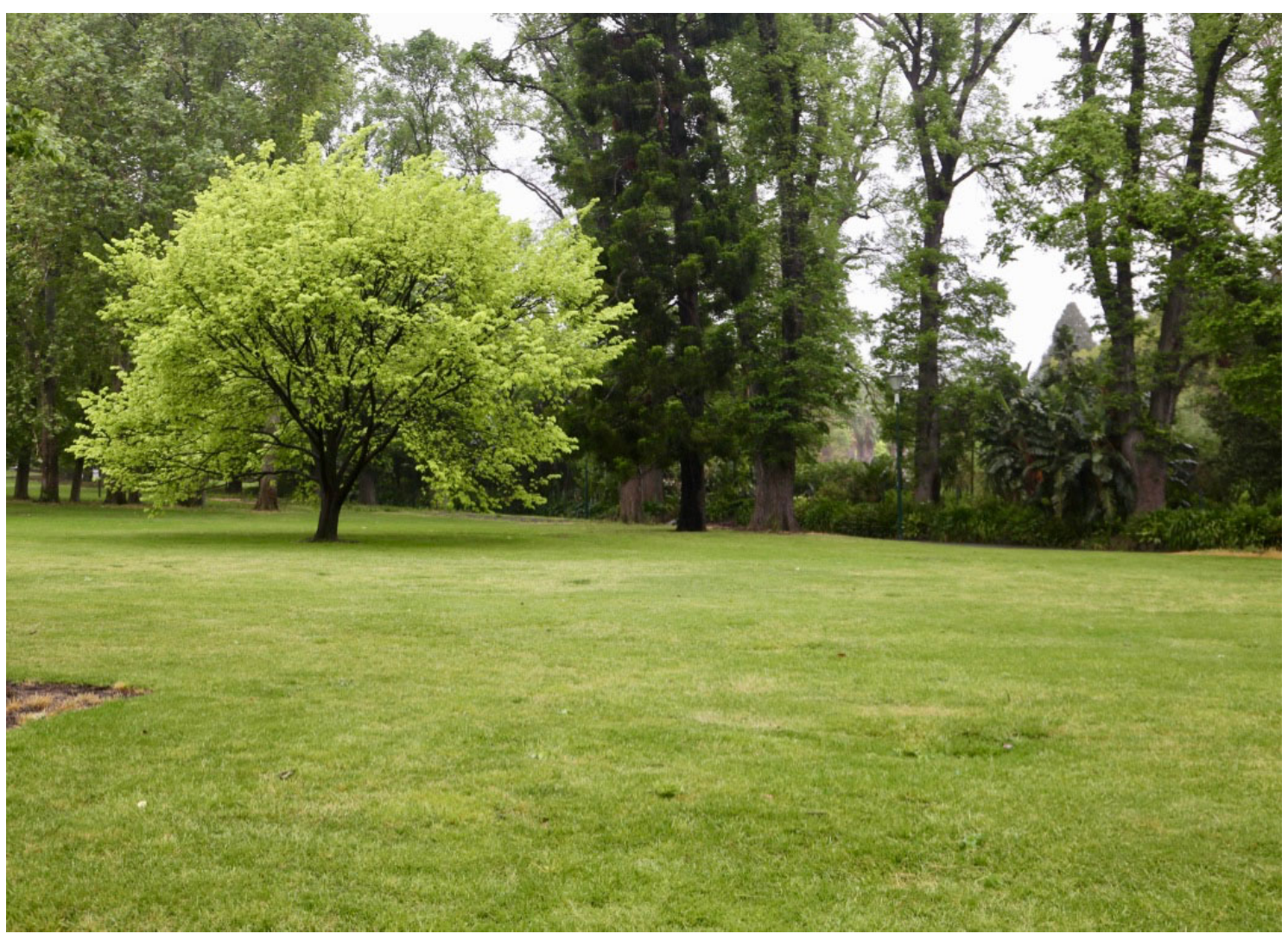

Figure 5. Golden Elm (Ulmus glabra 'Lutescens'), Fitzroy Gardens.2020.

Image credit: Scarlet Sykes Hesterman

After walking through avenues of established trees we paused beneath the canopy of a Golden Elm (Ulmus glabra 'Lutescens'). Our community of strangers were asked to consider the root systems of this tree, its canopy and root capacity hidden beneath the soil. Walkers were invited to gaze upwards with 'soft fascination'. In communing with trees in this way there is an opportunity for a reciprocal relationship with species 'more-than-human' (Head, 20I4).

At the Moreten Bay Fig Trees (Ficus macrophylla) walkers were invited to take a seated meditative posture amongst the buttressing roots of the fig or, lie on the ground looking upwards. A meditation was offered guiding the gathered human-beings to co-breathe with this expansive tree. Here human-beings could experience a relational collaboration, a mutualism with tree-beings. 


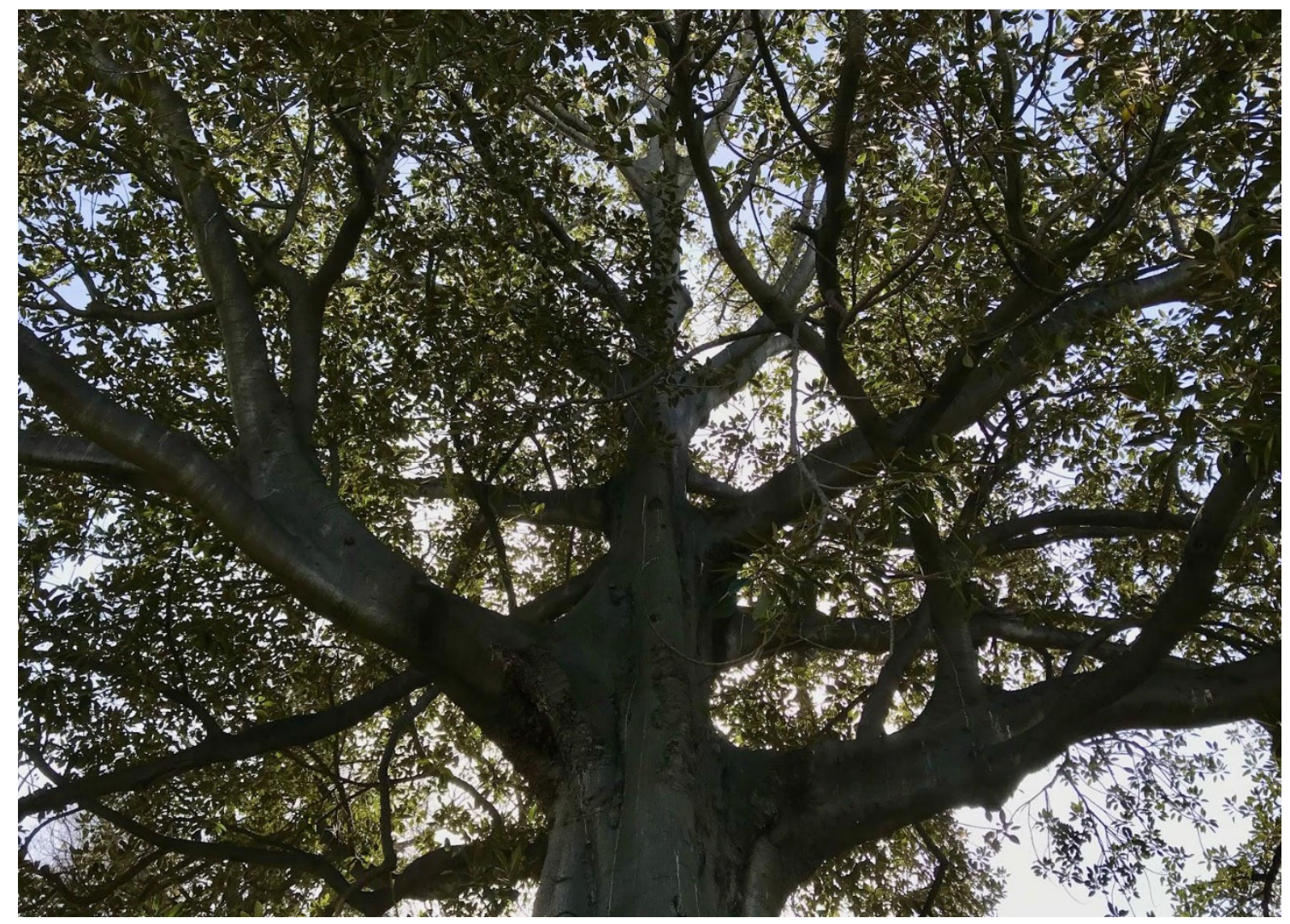

Figure 6. Moreton Bay Fig (Ficus macrophylla). Fitzroy Gardens 2020. Image credit: Scarlet Sykes Hesterman

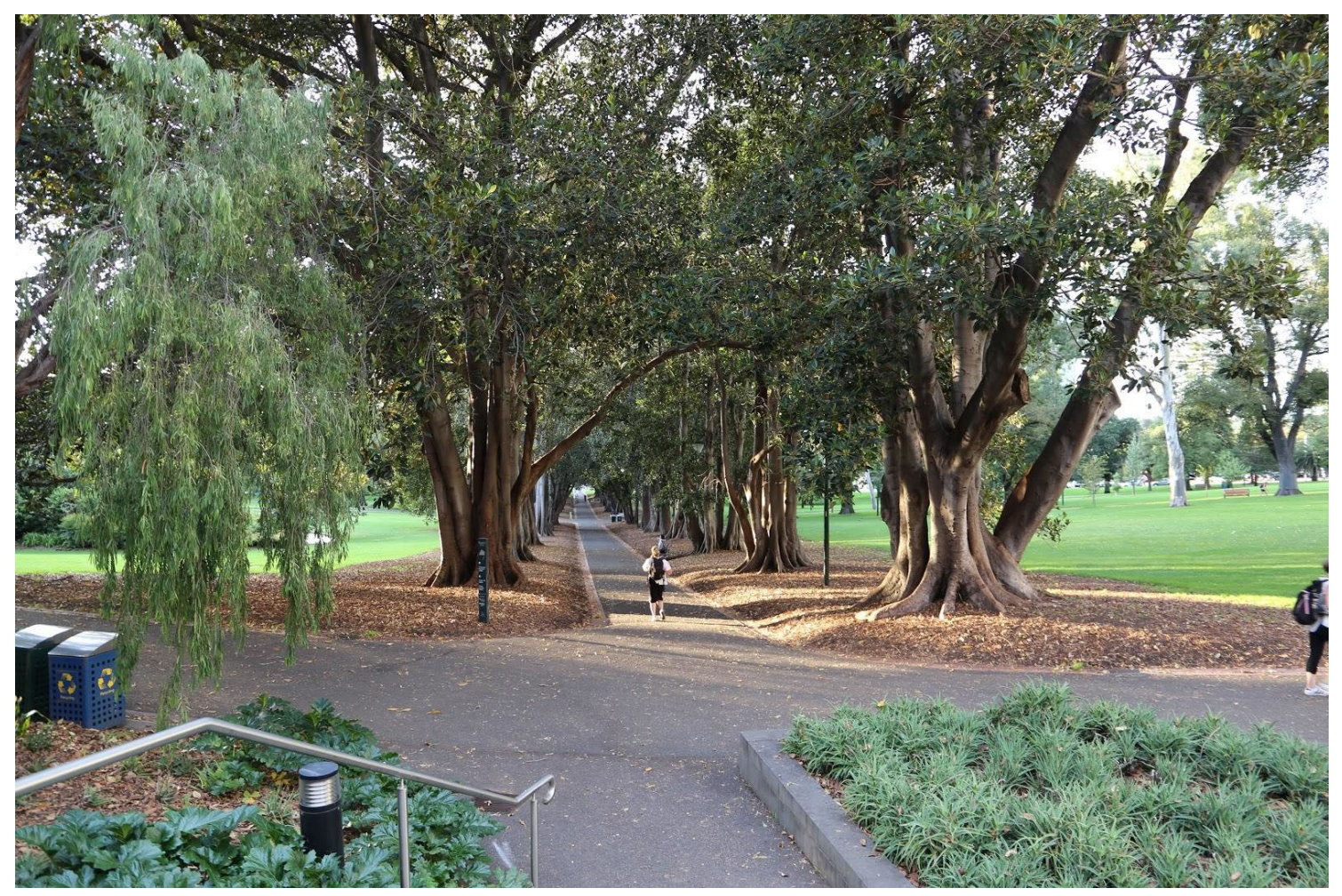

Figure 7. Moreton Bay Fig (Ficus macrophylla). Treasury Gardens 2020. Image credit: Heather Hesterman 
We invited walkers to view the garden through multiple lenses. In viewing the gardens through the lens of horticulture and landscape design, we invited participants to be conscious of pathways and adjacent plantings. As seen in figure 7, The Moreton Bay Fig Trees are planted either side of the pathway. Planting the same species and form, creates a vegetal verticality that acts as a counterpoint to the horizontal paths with repetition forming a pattern that both directs the viewer whilst aesthetically calming. Water features within Fitzroy Gardens were noted. Fountains, waterfalls, rhylls and pools provide a dynamism of movement and sound, as well as having calming and cooling effects. By stopping and inviting walkers to listen to the sound of water we drew attention to water as a precious resource. This is a poignant reminder of living in a dry continent.

We also asked walkers to reflect upon multiple narratives. Ideas from philosophy and anthropology invite us to re-look at the narratives and history of the site. The complexities of the space are evident in the garden's many built features as well as the design of garden beds that also reflect colonial and present fashions through plant selections.

Fitzroy Gardens exists because city planners recognised the value in establishing free public gardens and parks for health and recreation purposes. The idea that parks and gardens are beneficial to health was in the 1800's largely intuitively based. The gardens evolved over time with increased lawn areas evoking sweeping vistas in a Gardenesque style. Gardens are highly cultivated spaces whereby nature is domesticated via a hierarchy of power. Human interests are always at the forefront in the garden.

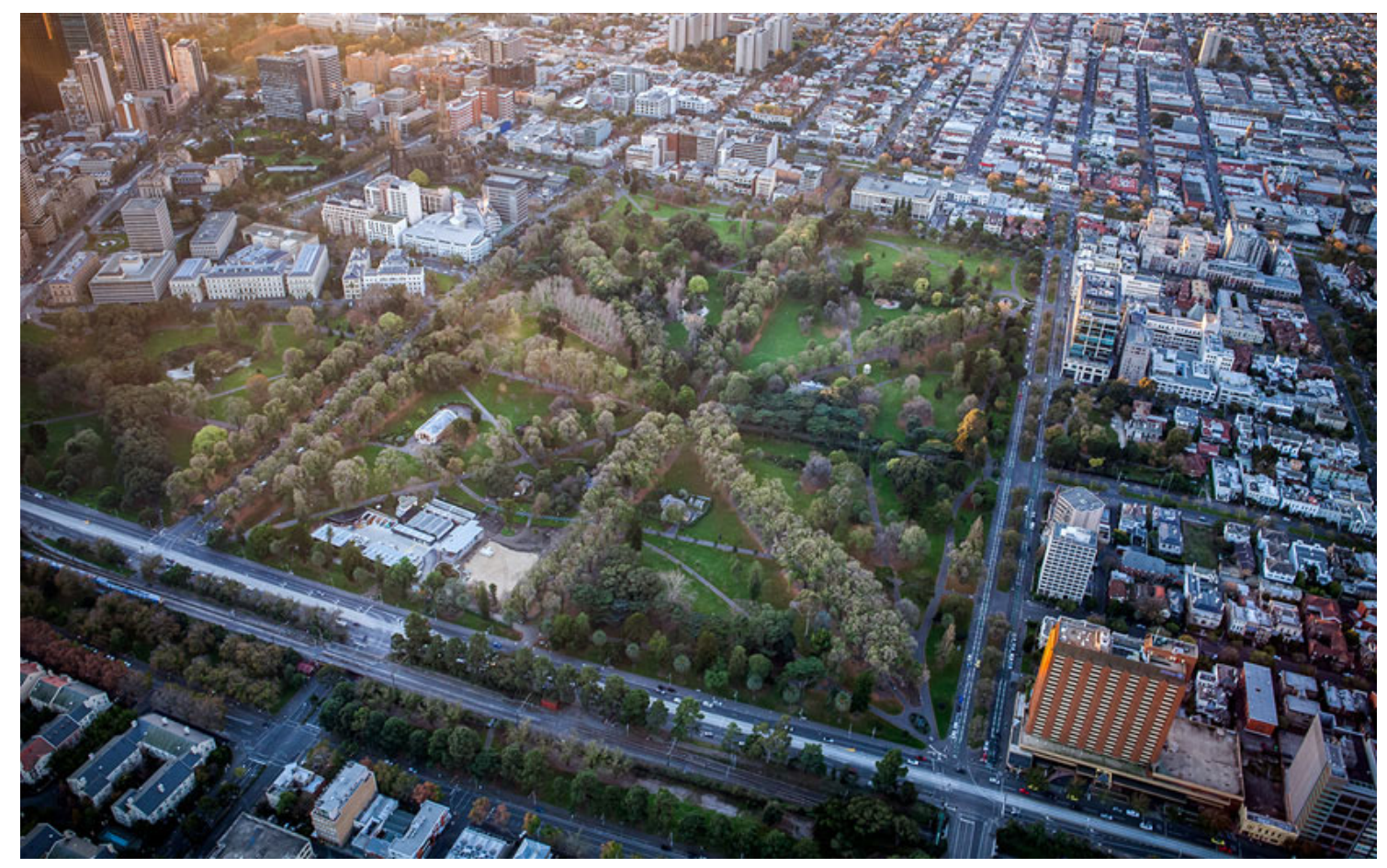

Figure 8. Aerial view of Fitzroy Gardens- Note radiating tree avenues references the Union Jack Flag. Image credit: Melbourne City Council. https://www.melbourne.vic.gov.au/fitzroygardens/waterinmelbourne/pages/fitzroygardenswater.aspx 


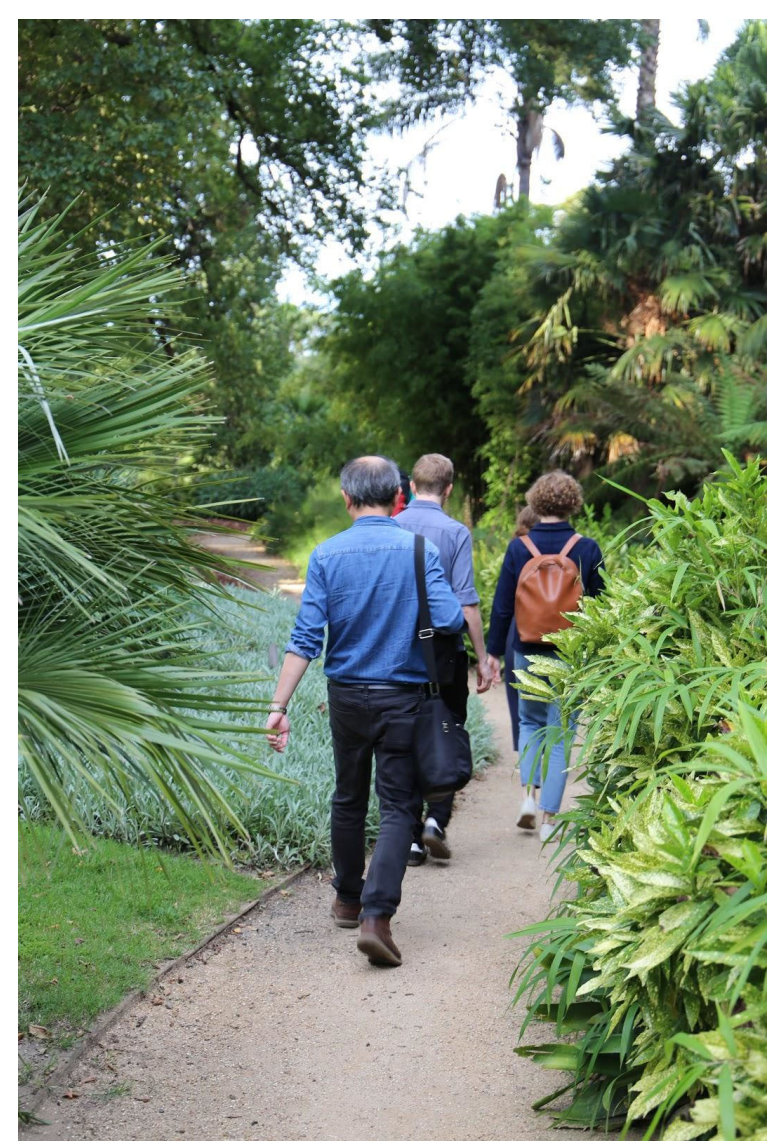

Figure 9. Treegazing walkers, Fitzroy Gardens. 2020. Image credit: Scarlet Sykes Hesterman

Treegazing shares a political agenda, a model of generosity that aims to shift modern society from 'consumption to contribution'(Sheldon,2019). The transition from the 'selfish', a form of 'greed economy'(Sheldon,2019) to a community that has enough. To promote more holistic thinking and actions towards nature and confront colonial and capitalist desires of our urbanised existence (Myers, 2018).

"Subtle activism" describes how consciousness-based practices like meditation and prayer can be a subtle form of social, environmental or political action. (Nicol,2015). Taking time out to walk and meditate in public space operates as a form of subtle activism on many levels. In viewing walking as an aesthetic practice, artist Hamish Fulton describes walks as a kind of pilgrimage, a symbolic environmental gesture employing text and photography. Fulton believes the only thing you should take out of the landscape are photographs and the only things you should leave are footprints (Auping, 1987). We were informed by Fulton's philosophy, seeing walking as a form of environmental care and a demonstration of subtle activism. 


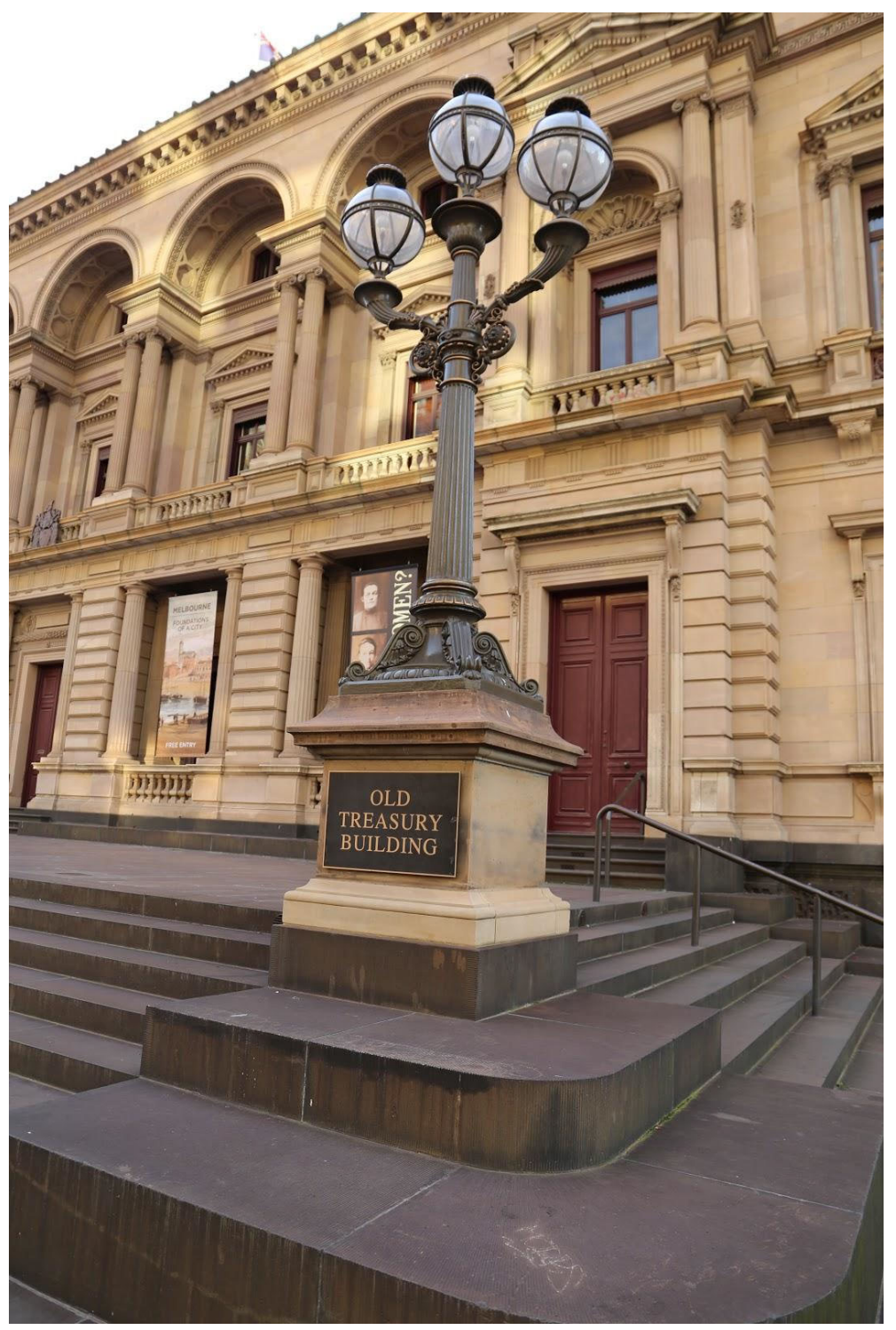

Figure 10. Old Treasury Building, Melbourne. 2020.Image credit: Scarlet Sykes Hesterman

We consciously began the walk at the Old Treasury Building, a colonial seat of power, with quarried bluestone. This site was specifically selected to reference the built environmental history and politics of Melbourne. This location has also been utilised for peaceful protest and social action rallies. We offered an 'acknowledgment of country' (this is a short greeting showing awareness of, and respect to, the Traditional Owners of the land on which a meeting or event is being held).

As white women we have benefited from the colonization of this country.

Public Gardens are the botanical and political legacies of colonization. 'Clearing' land involved removal of trees and readying it fit for farming or agriculture. We chose to conclude the walk at a remaining scar tree, a River Red Gum (Eucalyptus camaldulensis). It is a visual reminder of Indigenous peoples' ways of life as well as of colonial and settler occupations. 


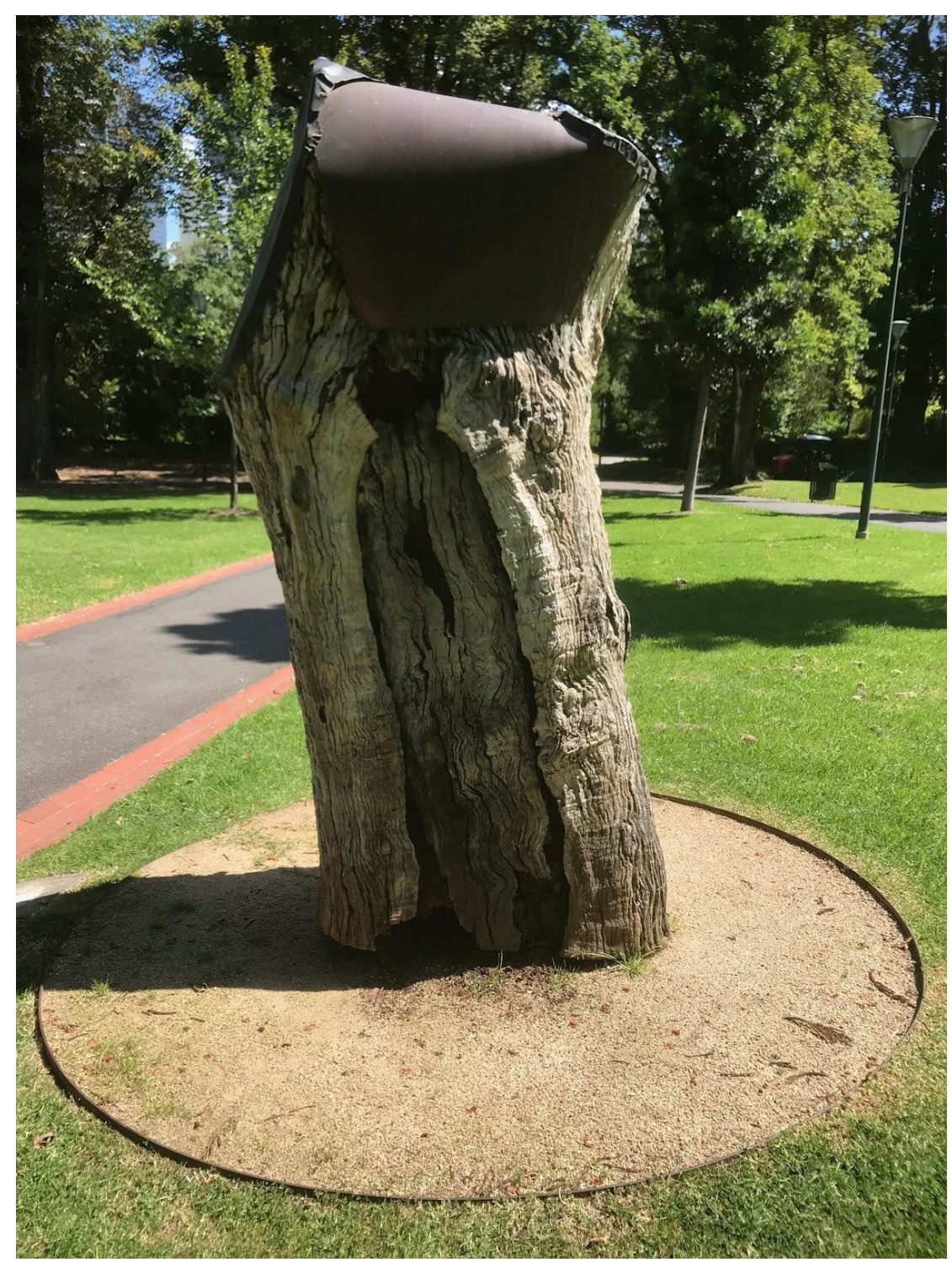

Figure II. Indigenous Scar tree, Fitzroy Gardens. 2020. Image credit: Heather Hesterman

This exemplifies a history where there has been an erasure of First Nations people by the dominant colonising culture. In this garden where numerous narratives are so clearly signposted there is cursory notation to the Indigenous, Traditional Owners of the land the Boon Wurrung (Bunurong) and Woi Wurrung (Wurundjeri) peoples of the Eastern Kulin Nation. Fitzroy Gardens exists at the cost of the removal of a whole integrated way of life. An embodied approach whereby Indigenous people lived collaboratively with rather than separately on the land.

Treegazing was an act of generosity and mutual trust from both ourselves and the walkers. This act embodies and weaves the individual with the other in a relationship of mutual respect and friendship. It suggests an environmental consciousness, a subtle activism whereby the economic self-melts away revealing a 'vibrancy of matter' (Bennett, 2012). Where at a cellular level verdant-beings, elemental earth and everything is connected. 


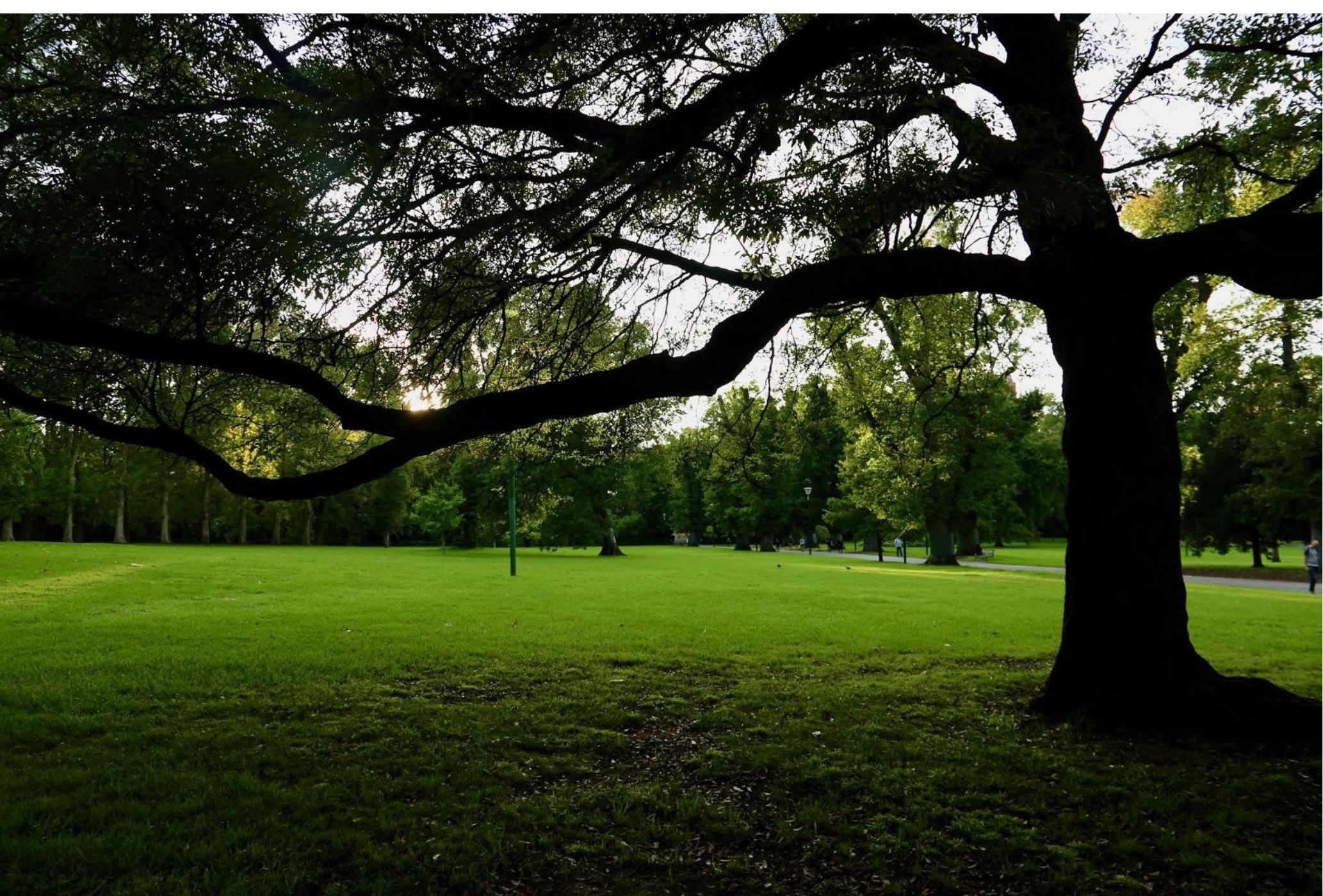

Figure 12. Fitzroy Gardens. 2020. Image credit: Heather Hesterman

As a result of this project, we suggest that 'walking in a landscape' offers more than photos. The effects of nature stay with us restoring and nourishing our minds and bodies. We composted mediative, landscape design and arts practices together. Critical theories informed our collaboration. Weaving together the complexities and features of the site illuminated multiple narratives. We specifically chose the start and end of the walk, to highlight a history of colonization. As part of this walk, we were committed to acknowledging Indigenous connections to land. Treegazing was designed to: give participants a temporal space; to notice the sensations of the body; to experience and connect with vegetal-beings and to come together as a community of strangers. In this moment of time Covid- 19 has caused us to live in radically different ways, whereby walking has new significances. We might reconsider how we connect with the world around us, how walking can be an act of subtle activism and how rethinking our relationships to everything might lead to more collaborative ways of 'living and dying well' (Haraway, 2016). 


\section{References}

Atchley, R. A., Strayer, D. and Atchley, P. (Dec 20I2) Creativity in the Wild: Improving creative Reasoning through immersion in natural settings. PLOS One: San Fran. 7(I2). Available at: https://doi.org/I0.137//journal.pone.005 I474 [Accessed I6 Sept. 2019]

Auping, M. (1987) A Nomad among Builders. In: J. Kastner (ed.), Nature: Documents of Contemporary Art. London: Whitechapel Gallery \& MIT Press. pp. 36-37.

Basu, A., Duvall, J and Kaplan, R. (2018). Attention Restoration Theory: Exploring the role of Soft fascination and Mental Bandwidth. Environment \& Behaviour. Volume: 5 I (9-10) pp. 1055-I08I. Available at: https://doi.org/I0.II77/00 I39/65/8774400 [Accessed 29 August 2020].

Bennett, J. (20I2) Vibrant Matter in Kastner, J.(ed) Nature: Documents of Contemporary Art. London: Whitechapel Gallery \& MIT Press, pP. 57-60.

Big Ideas, (2019) [radio] ABC, Radio National. 17 Jul. Available at: https://www.abc.net.au/radionational/programs/bigideas/sustainable-tourism/I I 302804 [Accessed I7 Jul. 2019].

Bunting, M. \& Kearney, P.( 20I6). A Practical Guide to Mindful Meditation. Melbourne: Hourigan \& Co.

Careri, F. (2009). Walkscapes : el andar como práctica estética = Walking as an aesthetic practice. Barcelona: Gustavo Gili.

Chodron, P. (July I5, 2020) Waking up to your world Lions Roar [online]. Available at: https://www.lionsroar.com/waking-up-to-your-world-pema-chodron/ [accessed 30 August 2020].

Corlett, R. (2015) The Anthropocene concepts in ecology and conservation. Centre for Integrative conservation, Xishuangbanna Tropical Botanical Garden. Trends in Ecology and Evolution, Vol.30(I) Available at: https://doi.org/10.1016/j.tree.2014.10.007 [Accessed 26 July 2020].

Fitzroy gardens (2020) Landscape History. [ONLINE] Available at: http://www.fitzroygardens.com/History.htm. [Accessed 22 September 2019].

Haraway, D. (2016) Staying With The Trouble: Making Kin In The Chthulucene. London: Duke University Press.

Head, L., Atchison, J., Phillips, C. and Buckingham, K. (20I4) Vegetal politics: belonging, practices and places. Social \& Cultural Geography, I5(8), pp. 86I-870. 
Kaplan, R. (1992) The psychological benefits of nearby nature. In: D. Relf (ed.), The Role of Horticulture in Human Well-Being and Social Development, vol. VI. Arlington: Timber Press, pp. 125-133.

Garfield Project (2020) What is Subtle Activism? [online]Available at: https://gaiafield.net/what-issubtle-activism/ [Accessed 22 August 2020]

Mancuso, S. (2018) The Revolutionary genius of Plants: A New Understanding of Plant Intelligence and Behaviour. New York: Atria Books.

Marder, M. (2013) Plant Thinking: A Philosophy of Vegetal Life. New York: Columbia University Press.

Myers, N. (2018) How to Grow liveable Worlds: Ten Not-So-Easy-Steps. In: K, Oliver-Smith, ed., The World to Come: Art in the Age of the Anthropocene. Gainesville: Samuel P. Harn Museum Of Art, University Of Florida, pp. 53-63.

Olmsted, F and Wood Roper, L. (1952) The Yosemite Valley and the Mariposa Big Tree: A

Preliminary Report (1865) Landscape Architecture Vol.43(I), Pp. 12-25. Available at: https://www.jstor.org/stable/44659746 [Accessed 20 August 2020]

Reich, W. T. (1995) Encyclopedia of bioethics. London: Macmillan Pub. Co.

Rosenberg, R. (1998) Breath by Breath: The liberating Practice of Insight Meditation. Boston: Shambala Pub.

Schussler, E. and Wandersee, J. (1999) Preventing Plant Blindness. The American Biology Teacher, 6I(2), pp. 84-86.

Strayer, D. (2020) Restore your brain with nature. [online] Available at: https://www.ted.com/talks/david_strayer_restore_your_brain_with_nature [Accessed 29 June. 2020].

Tsing, A. (2015) The Mushroom at the End of the World: On the Possibility of Life in Capitalist Ruins. New Jersey: Princeton University Press.

Townsend M and Weerasuriya R. (2010) Beyond Blue to Green: The benefits of contact with nature for mental health and well-being. Melbourne: Beyond Blue Limited. Available at:

https://www.deakin.edu.au/_data/assets/pdf_file/0004/310747/Beyond-Blue-To-GreenLiterature-Review.pdf [ Accessed 28 August 2020]

Williams, F. (2016) The Powers of Parks. National Geographic. Jan, pp. 48-67.

Williams, F. (2018) The Nature Fix: Why nature makes us happier, healthier, and more creative. New York: W.W. Norton \& Company. 